Aneta Grodecka

\title{
Aposiopesis albo figury myśli w dobie ucieleśnionego umysłu
}

A pustka zwraca ku nam twarz

i szepcze

„Nie jestem pusta, jestem otwarta”.

Tomasz Tranströmer, Vermeer

\section{Przemilczenie a zamilknięcie}

Michel Foucault w pracy Stowa i rzeczy. Archeologia nauk humanistycznych (1966) zauważyl, że w dyskursie ważne jest nie tylko to, co zostało powiedziane, ale również to, co zostało przemilczane. Jean-François Lyotard w Discours, figure (1985) uznał scenę dyskursu za pole szczególnie dramatycznej gry, którą toczą ze sobą mowa i milczenie; stwierdzil, że spotyka się tam to, co wizualne, i to, co nieświadome. Ocenil, że oko ucieleśnia w tej grze stronę „milczącej siły”, a nieświadomość oznacza nieprzezroczystość dla znaczenia (zmysłowość, „grubość”, „materialność”) [Lorenc 2001: 178]. Podobny układ sił obowiązuje w neurolingwistyce, której założenia wykorzystuje między innymi Bruce Duncan MacQueen. Wedle jego obserwacji, bardziej niż wypowiedź, która może istnieć hipotetycznie, w wyobraźni (można wytworzyć ją w umyśle), liczy się akt mowy - „czyn wykonywany w domenie mowy" [MacQueen 2010: 177]. Obejmuje on nie tylko rzeczywiście wypowiedziane słowa, ale również aspekty prozodyczne (ton głosu, tempo i głośność mówienia, melodię i rytm) oraz te niewerbalne (gest, mimikę twarzy, mowę ciała), a „nawet to, czego mówca nie wypowiedział - przemilczał, implikował, insynuował, 
traktowal jako zbyt oczywiste" [MacQueen 2010: 178]. To, co nieświadome, nieartykułowane, przemilczane, zaczyna odgrywać znaczącą rolę w humanistyce.

„Przemilczeć coś” lub „milczeć na jakiś temat” to określenia opisujące stan umysłu inny niż ten, do którego odsyła nas „zamilknięcie”. Zajmując się tym drugim stanem, wchodzimy do sfery, którą Maria Pąchalska nazwała „neuropsychologią milczenia”, i spotykamy tam ludzkie przypadki zamilknięcia oraz sposoby ich terapii, która okazuje się bardzo trudna w takich sytuacjach [Pąchalska 2010: 299]. W potocznym sensie - lub, jak określiłby to Ludwig Wittgenstein, $\mathrm{w}$,języku naturalnym” - stany zamilknięcia opisuje się jako rodzaj skrajnych doświadczeń, wynik skumulowania negatywnych emocji. Aby opisać skrajny gniew, mówi się, że to „woda gotująca się w imbryczku wysadziła pokrywkę i zalała ogień", czego śladem jest powiedzenie zanotowane w słowniku przysłów polskich „małe garnuszki prędko kipią” [Krzyżanowski, red. 1969: 603], wedle którego to ludzie niskiego wzrostu uchodzą za tych bardziej impulsywnych. Współcześnie dawne, XIX-wieczne, kulinarne metafory zastąpiły powiedzenia funkcjonujące w werbalnym kodzie świadomości potocznej, związane najczęściej z kulturą medialną, jak choćby: „urwał mu się film”, „zawiesił się”, „mózg mu się zresetował”, „mózg mu się zlasował”. Zmieniły się powiedzenia, lecz umysł funkcjonuje ciągle w podobny sposób.

Stany mentalne, które rejestruje sztuka, próbowano wyjaśniać za pomocą figur retorycznych. Wedle koncepcji Jerzego Ziomka, rozwijanej przez Sewerynę Wysłouch, figury myśli to tropy odnoszące się do „myślenia, władz myślenia, zawartości myślenia, po grecku schemata tes dianoias" [Ziomek 2008: 164]. Mają one zastosowanie w opisie interdyscyplinarnych zjawisk artystycznych, u ich podstaw „leżą uniwersalne operacje, których źródeł szukać należy w ludzkim mózgu i które są niezależne od materii” [Wysłouch 2009/2010]. Pomysł wiązania tropów z umysłem twórcy zawierała także koncepcja „czytania literatury” Harolda Blooma - choć oparta była na innych założeniach światopoglądowych, w jej ramach również lączyły się tekst i psyche, a klucz do sfery interpretacji stanowiły właśnie poetyckie tropy. Metodę Blooma trafnie opisał John Hollander: 
Dla Blooma trop to skręcona lina transformacyjnego procesu, zakotwiczona w głębinach o skałę ekspresyjnych potrzeb, napięta i biegnąca ku powierzchni, gdzie przyczepiona jest do płaskiej kartki tekstu. Formalistyczne i strukturalistyczne odczytania przypominałyby mniej lub bardziej szczegółowe plany powierzchni tekstu, które pozwalają zobaczyć jedynie końcówkę liny tropu. Blooma interesuje cała ciągłość tej liny, warstwy wszystkiego, przez co ta lina przechodzi (cokolwiek to jest), sposób, w jaki na pewnych poziomach te skręcone liny mogą kierować się w inną stronę niż zamierzona droga ku górze, względnie stopnie napięcia lub poluzowania liny, i tak dalej. [Hollander, cyt. za Bloom 2003: 104-105]

Bloom - zainspirowany przez psychoanalizę - skupiał się na sferze doświadczeń autora, tropił nieświadomość w czasach, gdy neuronauka nie odkryła jeszcze nowego zakresu tego pojęcia. Współcześnie obowiązują już nowe metodologie, w których umysł i empiria wchodzą w ciekawe związki. Sugerowany w nich splot filozofii oraz medycyny odsłaniał w swoich pracach António Damásio, zwolennik teorii ucieleśnionego umysłu. Dowodził on, że to emocje formują naturę naszego umysłu, świadomość i sposób komunikacji. Na potrzebę syntezy metodologii naukowych wskazuje współcześnie Włodzisław Duch, który wiąże przestrzeń psychologiczną i stany w mózgu, wywodząc zasady nowej dyscypliny z pism Edmunda Husserla i Romana Ingardena oraz z badań Rogera Sheparda [Duch 2013].

W nowym kierunku badań ważne okazuje się zatem holistyczne postrzeganie stanów mentalnych jako swego rodzaju procesu, w którym genetyczny i neuronalny determinizm łączą się $\mathrm{w}$ syntetycznym splocie, a uwarunkowania wewnętrzne są równie ważne jak doświadczenia i zewnętrznie kształtowane nawyki. Określenie „proces” jest tu bardzo istotne, gdyż chodzi o to, by porzucić dążenie do tworzenia mapy umysłu, czyli paradygmat obowiązujący od czasów Carla Wernickego, oparty na przekonaniu, że wszystkie procesy umysłowe można podzielić na konkretne funkcje wykonywane przez określone obszary (ośrodki) mózgu. Zgodnie z tym założeniem postępują 
jeszcze kognitywiści', którzy nadal poszukują schematów, choć ich rozwiązania - jak określa to Pąchalska - wydają się bardziej subtelne i złożone. „Podstawą pracy mózgu jest proces, który wynika z działania systemu, a nie funkcja, która wynika z działania danej struktury” [Pąchalska 2010: 312]. „Nowa mapa mózgu" nie akcentuje już podziału na półkule mózgowe, inaczej rozkłada punkty ciężkości - wiąże działanie umysłu z rozwojem ewolucyjnym. W myśl odświeżonej przez neuronaukę koncepcji Paula MacLeana dysponujemy trzema mózgami: mózgiem gadzim, paleossaków i nową korą, co zresztą odpowiada dawnemu Arystotelesowskiemu podziałowi duszy na wegetatywną, zwierzęcą oraz rozumną [Duch 2017]. Mózg gadzi obejmuje pień mózgu i jest odpowiedzialny za wszystkie podstawowe funkcje przetrwania, głód, oddychanie, bicie serca, strach, ale też „mordowanie z zimną krwią”. Mózg paleossaków obejmuje układ limbiczny i odpowiada za emocje oraz zachowania społeczne, stres, przyjemność, przywiązanie. Kora nowa, która dzieli się na płaty (potyliczny i czołowy), korę przedczołową i szarą materię, odpowiada za procesy poznawcze, a także za rozwiązywanie problemów. Tak rozłożone funkcje i ich wzajemne relacje zmieniły sposób, w jaki pojmujemy współcześnie inteligencję. Okazało się, że racjonalne aspekty, związane z myśleniem czy planowaniem, są w równym stopniu rozwinięte zarówno u człowieka, jak i u innych naczelnych i delfinów. Zachowanie człowieka to wynik zintegrowanego oddziaływania tych trzech struktur mózgu, myślenie podlega działaniu szeregu reakcji nieświadomych, zachodzących bez kontroli. Opis myślenia, wykreowany w ramach neuronauki, może przerażać humanistę. John Bargh trafnie zauważa:

Wszystkim nam bliska jest koncepcja, że pozostajemy panami własnej duszy, że to my o wszystkim decydujemy, a myśl, że mogłoby być inaczej, jest zwyczajnie straszna. Przecież właśnie przypisując każde wydarzenie określonemu „procesorowi”, który odpowiada za poszczególne funkcje. 
na tym polega psychoza - na poczuciu oderwania od rzeczywistości, wrażeniu utraty kontroli. A to uczucia, których boją się wszyscy. [Bargh, cyt. za Mlodinow 2016: 27]

Stoimy zatem nie jedynie przed wyborem metodologii, ale przed decyzją światopoglądową. Francisco Varela formułując założenia neurofenomenologii, dowodzi, że akceptacja obszarów nieświadomości, udziału mózgowych zombie w naszych zachowaniach ${ }^{2}$, nie musi oznaczać utraty rozumu. Badacz zakłada również, że pomiędzy intuicją a rozumowaniem nie istnieje żadna sprzeczność, gdyż intuicja bez rozumowania jest ślepa, zaś pojęcia bez intuicji są puste [Varela 2010: 50].

\section{Aposjopeza pomiędzy świadomością a nieświadomością}

Aposjopeza czy aposiopesis to figura znana literaturoznawcom [zob. Korwin-Piotrowska 2015: 142-153] i muzykologom [Lisecki 1993]. Mechanizm aposiopesis odnosi się do grupy figur przez detrakcję, czyli „wszelkie pominięcie (praeteritio) wywodu, który w naturalnym porządku rzeczy powinien był wystąpić” [Ziomek 2008: 164]. Wedle hasła słownikowego aposjopeza oznacza „przerwanie wypowiedzi i porzucenie pewnego wątku motywowane wzruszeniem, odrazą, wstydliwością” [Okopień-Sławińska 1989: 37-38] [3. Elipsa, w odróżnieniu od aposiopesis, opisywana jest w słowniku jako figura kompletna znaczeniowo, a niepełna jedynie w sensie konstrukcyjnym. Należy rozważyć adekwatność tych ustaleń do współczesnej praktyki artystycznej oraz neuronauki. Raoul Schrott i Arthur Jacobs odnajdują mechanizm aposiopesis już w poezji starożytnej, między innymi w groźbie Neptuna wypowiedzianej na początku Eneidy Wergiliusza. Za symptom współczesnej aposjopezy uznają zaś fragment ekfrazy Vermeer Tomasza klasyfikacji Macieja Kazimierza Sarbiewskiego aposiopesis zaliczono do figur mających wywołać wzruszenie, figurae ad movendum, lącznie z eksklamacją, aversio, supplicatio [Sarbiewski 1958]. 
Tranströmera (z tomu Żywym i umartym z 1989 roku) odnoszący się do obrazu Kobieta $w$ błękitnej sukni"

Obrazy nazywają się „Lekcja muzyki”

Albo „Kobieta w niebieskiej sukni czytająca list” -

ona w ósmym miesiącu, dwa serca w niej kopią.

$\mathrm{Na}$ ścianie w głębi wisi pomarszczona mapa Terra Incognita.

Oddychać lekko... Nieznana błękitna materia przygwożdżona do krzeseł.

Złote nity wleciały $\mathrm{z}$ niesłychaną prędkością

i z nagła zastygły

jakby nigdy nie były niczym prócz spoczynku.

[Tranströmer 2012: 318]

Wedle ich omówienia:

Motyw efektownego zamilknięcia, zatajenia czegoś ważnego, co jest powiedziane między linijkami, występuje tutaj trzykrotnie. Płynny opis pomieszczenia zostaje przerwany za pomocą pustej linijki, zmiany perspektywy i emocjonalnego imperatywu „oddychać lekko”. Taki sens wzmacnia wielokropek, który oznacza zwrot wyrażający zamilknięcie. Dzięki tym zabiegom zamilknięcie staje się przekazem wiersza. [Schrott, Jacobs 2011: 448]

Czy jednak w tym wypadku można zrekonstruować niedopowiedzianą myśl? Poetycka refleksja dotycząca „oddychania” może odnosić się zarówno do ciężarnej kobiety, jak i podmiotu patrzącego, do którego dotarło właśnie mistrzostwo pędzla zaznaczające się w tych partiach obrazu, gdzie modelowane jest aksamitne obicie krzesła. Oddane za pomocą aposjopezy doznanie może odnosić się także do sfery odbioru - to czytelnik zauważa związek pomiędzy ekspresją artystyczną a „wiecznością”. Nie sposób stwierdzić,

4 Jan Vermeer, Kobieta w btękitnej sukni, ok. 1662-1665, olej na płótnie, $46,5 \times 39 \mathrm{~cm}$, Rijksmuseum. 
o jakie dopowiedzenie stanu niedookreślonego chodzi. Zgodzić się należy, że skrótem urwanej myśli jest w poezji najczęściej wielokropek [Korwin-Piotrowska 2015]. Warto jednak pamiętać, że ten sposób graficznego wyróżnienia jest kulturowo i semantycznie zróżnicowany ${ }^{5}$ - na przykład Cyprian Norwid stosował w tym zakresie cały rejestr autorskich oznaczeń [Subko 1990; Rogowska 2012], a one następnie ginęly (i nadal giną) $\mathrm{w}$ druku' . To powoduje, że jakość przekazu i - co za tym idzie - jakość interpretacji pozostają zaburzone.

Nagłe przerwanie mowy w muzykologii zyskało znaczenie szersze omówienie, okazuje się bowiem, że może mieć wiele znaczeń. Aposiopesis lokuje się w kręgu figur emfatycznych i - jak objaśnia Wiesław Lisecki - obejmuje trzy następujące warianty:

- cisza - najczęściej symbolizuje śmierć lub pustkę po stracie kogoś bliskiego;

- łkanie lub westchnienie - lagodne przerwanie wypowiedzi pauzami;

- nagłe zerwanie, przerwanie wątku - oznacza grozę, niemożność kontynuacji z powodu wielkiego wzruszenia lub oburzenia. [Lisecki 1993: 11]

W pierwszym wariancie nazwa jednostkowa i ogólna są tożsame, zwykle podaje się, że aposiopesis oznacza dłuższą pauzę symbolizującą ból, rozłąkę, cierpienie, śmierć, czego dobrym przykładem jest fragment z Pasji wedlug św. Jana Johanna Sebastiana Bacha, moment, gdy „po słowach «und neiget das Haupt und verschied» (i skłoniwszy głowę, oddał ducha) zapada nagła cisza symbolizująca śmierć Chrystusa; i dopiero po tej pauzie chór śpiewa arię Mein teuer Heiland" [Lisecki 1993: 11]. Z uwagi

5 Wedle podręczników gramatyki amerykańskiej trzy kropki są wykorzystywane do wskazania pominięcia w środku oświadczenia lub w cytacie, a cztery punkty gdy pomija się fragment na końcu zdania.

6 Jak podaje Elżbieta Lijewska, według wewnętrznej instrukcji redakcyjnej wychodzących teraz Dziet wszystkich wszelkie autorskie „wielokropki” zasadniczo zamienia się na trzy kropki, zaś Norwid niekiedy stawiał tych znaków tyle, ile mu zostało miejsca w wersie. 
na poezję ważniejsze są jednak dwa następne warianty muzycznej aposjopezy: suspiratio i abruptio (czyli tmesis). Przykładem pierwszej odmiany jest moment w kantacie Bacha Ich hätte viel Bekümmerni $\beta$, gdy słowa arii Seufzer, kummer... przerywają dramatyczne pauzy. Trzeci wariant, abruptio, to „muzyczna aborcja” - nagłe zerwanie narracji będącej w pełnym toku. Przykładem jest scena przeklinania Judasza w Bachowskiej Pasji według św. Mateusza, czyli partie chóru Sind Blitze, sind Donner zu Wollken verschwunden. To moment, gdy „pytania ciągle piętrzone umilkną nagle w kulminacyjnym momencie i po tej pauzie - abruptio - dopiero chór zaczyna swoje przekleństwa" [Lisecki 1993: 11]. W muzyce, co istotne, $\mathrm{z}$ aposiopesis spokrewniona jest również ellipsio (synekdocha), czyli figura związana z mechanizmem narastającego napięcia prowadzącego do zerwania wypowiedzi. Lisecki przywołuje tu fragment z madrygału Claudia Monteverdiego Hor che'l ciel e la terra, gdzie po pierwszej strofie sonetu Francesca Petrarki kompozytor wprowadza gwałtowaną gradację wraz ze słowami „vegilio, vegilio, penso, arde” („czuwam, czuwam, myślę, płonę”):

Krótkie, ostro akcentowane akordy oddzielane pauzami tworzą gradację, podobnie jak i słowa (każde następne jest bardziej nacechowane dynamicznie w stosunku do poprzedniego). Jednak w wierszu ta gradacja zawiera jeszcze jedno słowo piango („płaczę”). Jest ono kulminacją. Monteverdi natomiast to ostatnie słowo wyłącza $\mathrm{z}$ tego gradacyjnego procesu i opracowuje w postaci kadencji. [Lisiecki 1993: 20]

Poetyckiej aposjopezie najbliższe jest muzyczne abruptio, zamilknięcie motywowane uczuciem grozy, wzruszeniem czy oburzeniem (ważne są tu określone stany uczuciowe). Dalsze przykłady odsłonią, na ile czytelna może okazać się rekonstrukcja takiego stanu.

\section{Poetyckie abruptio}

Aposiopesis przyłożona do twórczości Zbigniewa Herberta wywołuje wielokrotnie analizowane i cytowane Przestanie Pana Cogito, a dokładniej wers „powtarzaj stare zaklęcia i legendy, bo tak 
zdobędziesz dobro, którego nie zdobędziesz" [Herbert 1982: 255]. Wydawałoby się, że najlepszym rozwiązaniem będzie dopełnienie, iż znajomość „legend” jest niezbędna, by zyskać pełnię wiedzy i wrażliwości. W zapisie może jednak chodzić o coś więcej. Zasadne jest przypuszczenie, że zakodowany został tam bardziej rozbudowany emocjonalny scenariusz, na przykład: „Musisz studiować dawne legendy, musisz tak robić, tysiąc razy Ci mówiłem, że nie ma innej drogi, tylko w ten sposób pozyskasz wartość, której nawet nie spodziewasz się zdobyć”. Zakłócenie logiki w wersie może więc prowadzić do różnych wyjaśnień. W momencie rekonstrukcji napotykamy na barierę w postaci języka, opis mechanizmu mentalnego, jak ten zacytowany powyżej, może wydawać się banalny. Jednak nie ma innej drogi niż prosta deskrypcja doświadczenia, pomocny w tym okazuje się niejednokrotnie ton wypowiedzi, który staje się - jak powiadał Ingarden - quasi-sądem w postawie estetycznej [Ingarden 1957: 428] i jest dostępny zarówno w tekście ustnym, jak i pisanym:

Rozumiejąc dobrze dane dzieło literackie umiemy [... ] odpowiednio je przeczytać, resp. „zadeklamować”, a więc dobrać ten właściwy ton, czy ogólniej sposób wypowiedzenia słów i całych zdań utworu, który - że tak się wyrażę - „prosi się” $\mathrm{w}$ danej sytuacji. [Ingarden 1947: 62]

W zgodzie z powyższym i z założeniami neuropsychologii rozstrzygający jest ton Herberta podczas deklamacji tego zdania, który usłyszeć możemy w zachowanym nagraniu [Zbigniew Herbert czyta... 1999]. W czasie recytacji wersu poeta poczynił dwie długie pauzy (których nie zaznaczył w tekście) po słowach „bo” i „tak”. One uruchamiają scenariusz zakodowany w wersie, odsłaniają emocjonalną głębię i przygotowują na nią (to rodzaj przykucia uwagi). Trudno ustalić, jak przebiegają napięcia w owej głębi. Zbadano już dość dokładnie mechanizm przepływu emocji w umysłach psychopatycznych i ustalono, że nadmiar bodźców pochodzących ze strefy korowej hamuje ciało migdałowate oraz mechanizmy empatii, co sprawia, że taki umysł przestaje czuć. W przypadku omawianego wersu może chodzić o proces 
odwrotny: to nadmiar bodźców czuciowych przerywa nić intelektualnej precyzji, wtedy słowo „rwie się”, a w toku narracji powstaje cisza. W przypadku tego fragmentu założyć musimy także udział procesów nieświadomych.

Aposiopesis dominuje w tekście Herberta Pora z tomu Epilog burzy, figurę tę spotykamy już w pierwszej strofie:

o poro w nieboskłonów wnętrze wszystko już zamknięte kształt dźwięk i kolor z lekka wywinięty jest tylko płatek róży rdzawy już po brzegu. [Herbert 1998: 67]

Ten medytacyjny fragment tworzy rodzaj pejzażu wewnętrznego. Relację podmiotu organizuje podziw. To rodzaj emocji nietypowej, która, podobnie jak gniew, nie odnosi się wprost do „nosiciela”. Wyrażone w strofie doznanie pełni to zapis wielozmysłowych doznań: w zamkniętej przestrzeni splatają się kolor i dźwięk.

W drugiej strofie wiersza aposiopesis staje się podstawową zasadą wyrazu:

słodkie nieróbstwo nie pytać o zmierzchu

Boreasz rzeźbi chmury a Cyrrusy resztę

czarny i biały Norwid i wyrzut sumienia?.

Wchodzimy w przestrzeń mentalną głębiej, zgodnie z zasadą wywiedzioną z sonetu. To opis pory zmierzchu, gdy podmiot ulega prawom, wobec których rozum niewiele znaczy, poddaje się działaniu sił wyższych. Ostatni wers jest bardzo ciekawy. Tu myślenie ustępuje emocji, a ta wydaje się ambiwalentna. Z jednej strony podmiot odwołuje się do esejów Norwida i ulega nostalgii oraz odczuwa niepokój związany z losem zmarłych artystów, którzy za życia nie zaznali aplauzu. Z drugiej strony pojawia się w jego umyśle wyrzut sumienia. Czy możliwe jest jednoczesne odczuwanie takich dwóch różnych stanów? Co oznacza „wyrzut sumienia”? W tym momencie nie możemy dokonać precyzyjnej rekonstruk-

7 W opublikowanym utworze widnieje „Boreusz” zamiast „Boreasz”. 
cji, tej niejednoznaczności nie sposób ująć w porządku temporalnym. Pozostajemy z wątpliwością, „czy ambiwalencja to podwójny, zachodzący jednocześnie jeden stan umysłu, czy też pulsujące naprzemiennie dwa stany umysłu?” [Pąchalska 2010: 304]. Gdy czytamy ten wiersz, nie możemy być pewni wniosków, możemy jedynie obserwować proces mentalny, kryjący się za zawieszeniem głosu, obcować z zapisanym strumieniem postrzeżeń, rodzajem idealnego stenogramu doświadczenia.

\section{Malarska elipsa}

W muzyce pauza odczuwana jest jako wyraz emocjonalnych jakości. Czy w podobny sposób oddziaływają zakodowane w malarstwie wzorce wizualne, takie jak kąty, linie i krzywe? Twierdząco odpowiedział na to pytanie Robert Arnheim i tym samym tropem podążają współcześnie neuroestetycy. Gdy poszukujemy aposiopesis w malarstwie, stajemy wobec efektów szkicowości i niedokończonej kreski, które są nieodłączną częścią malarskiego warsztatu. Zagadnienie wymaga zatem selekcji przykładów. W przypadku obrazów dawnych przywiązywano dużą wagę do tak zwanych „obrazów mówionych”, gdy gest czy wyraz twarzy współtworzyły przesłanie dzieła. Ten gatunek miał swoich mistrzów - jednym z nich był Rembrandt, który w zakresie przekazu emocjonalnego powiedział, jak na swoje czasy, zadziwiająco wiele.

Przykładem reprezentacji stanu „zamilknięcia” jest Śpiewajacy chtopiec $z$ fletem Fransa Halsa [ryc. 1, s. 98]. W namalowanym geście kryje się semantyka. Ważny okazuje się ruch ciała, który „ma swoją jakość temporalną, [...] liczy się sposób, w jaki akt jest wykonywany, co pociąga za sobą: napięcie, linearność, amplitudę i projekcję" [Johnson 2015: 46]. Gest flecisty okazuje się wiele mówiący, a jednocześnie zawiera w sobie milczenie, sferę niedookreśloną, której w prosty sposób nie można opisać (to na niej zasadza się przekaz obrazu).

Aposiopesis znajduje zastosowanie w szczególnej - muzycznej-odmianie malarstwa [Szerszenowicz 2008]. Można odnaleźć ją we współczesnych obrazach tanga Wojciecha Pakmura. Emocja - jej doza, a nie sam fakt obecności - rozsadza formę tych prac. 


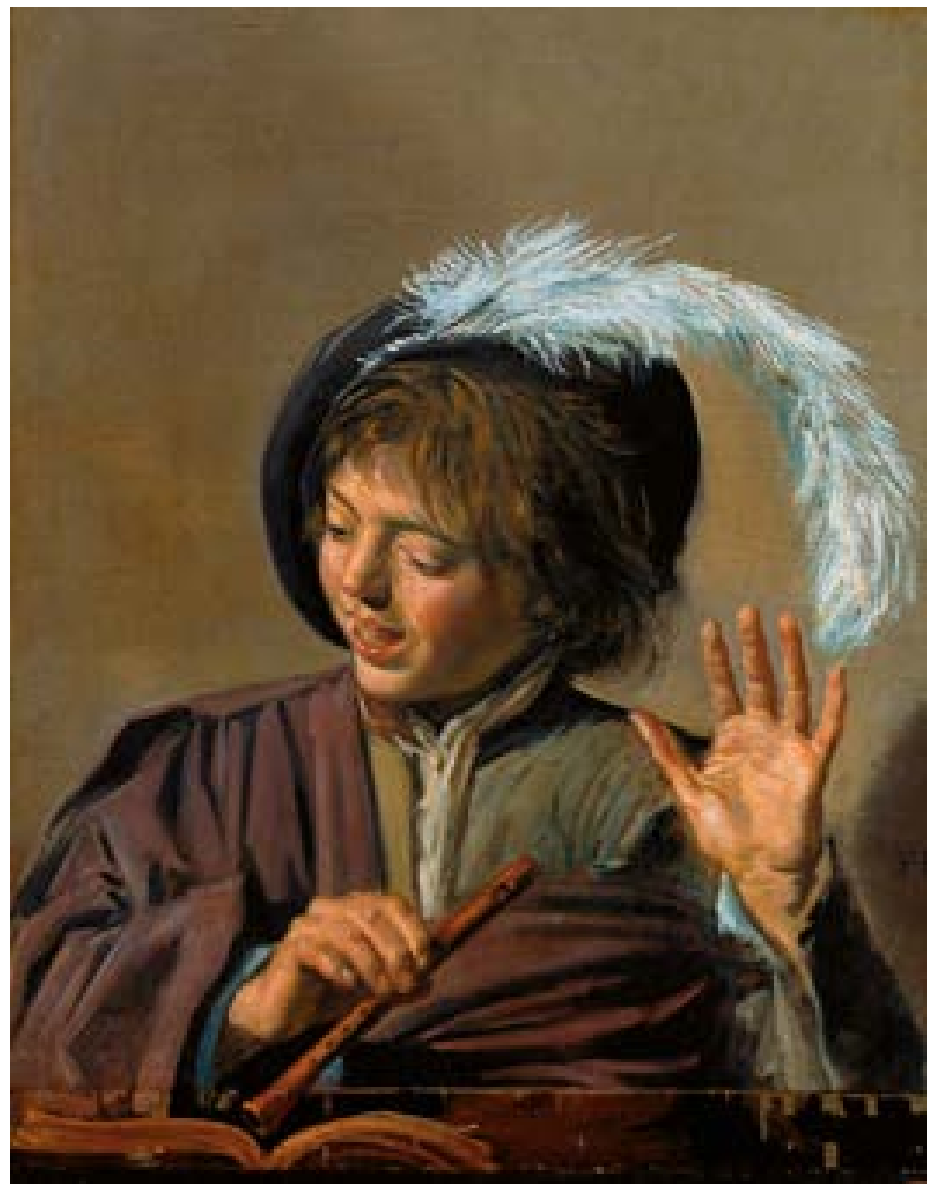

Ryc. 1 Frans Hals, Śpiewajacy chtopiec z fletem, 1625, olej na płótnie, $62 \times 54,5 \mathrm{~cm}$, Gemäldegalerie w Berlinie

Ważne są momenty niedokończenia (ale te stosował już Edgar Degas), ważny jest rodzaj kreski (choć taki balans spotkamy już u Henriego de Toulouse-Lautreca). W przypadku prac Pakmura istotne są też nowe efekty uzyskane poprzez zastosowanie kredkowej akwareli. Istotny okazuje się również sam motyw, czyli tango argentyńskie - forma tańca wywiedziona z ulicy, z portowej tawerny, oparta na namiętności, prymitywnej sile i improwizacji. Mechanizm aposiopesis obserwować możemy w dwóch poniższych studiach malarskich Pakmura. 


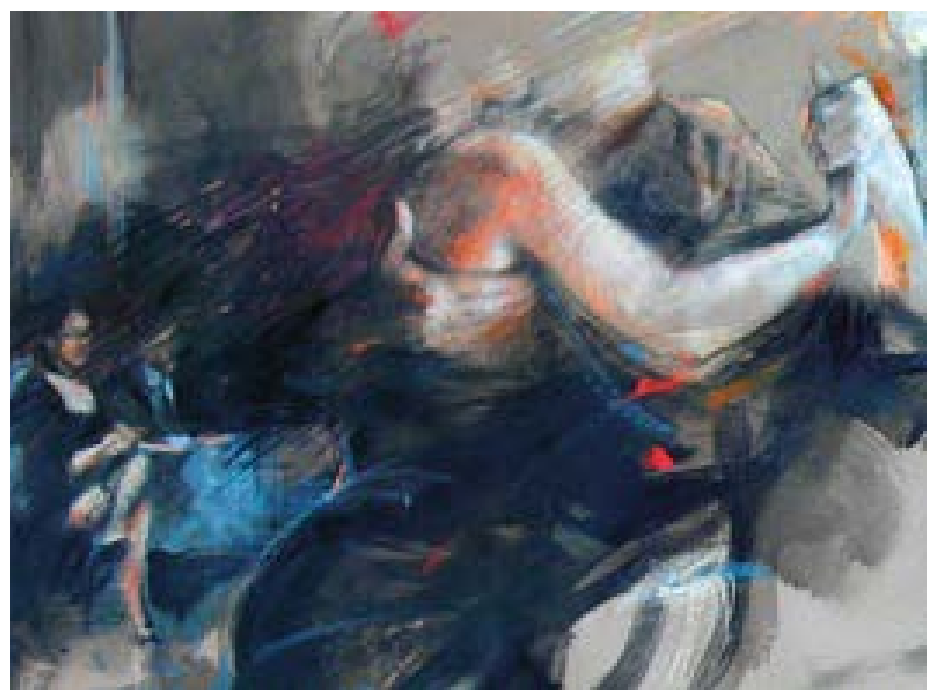

Ryc. 2 Wojciech Pakmur, Tango - impression 3, 2003, technika mieszana, $100 \times 120 \mathrm{~cm}$, kolekcja prywatna

Na obrazie powyżej [ryc. 2] ważna jest relacja pomiędzy pierwszym i drugim planem: to obraz tańczącej pary, spiętej w tańcu, oraz pary siedzącej w tle, która zajęta jest rozmową i ujęta została z odległości. Sylwetki tancerzy widoczne są jedynie połowicznie, nie widzimy ich twarzy ani nie obserwujemy ruchu nóg. „Ucięcie” postaci uznać należy za odważne (takie japońskie kadrowanie znane jest w historii wizualizacji), lecz nienamalowana część wizerunku okazuje się niepotrzebna dla widza, domyśla się on tego, co jest niewidoczne. Na tym Pakmur jednak nie poprzestaje. Można zauważyć, że obraz pozbawiony został ogniskowej, jakiegoś stabilnego bieguna, oparto go na przestrzeni pozbawionej stałej zasady. Spojrzenie odbiorcy skupia się na ręce mężczyzny obejmującej kobiecą kibić, to wprowadza do przedstawienia walor dotykowy. Ważna staje się nie iluzja, ale aktywność „energetyczna”. Doznanie jest silne, wizerunek nasyca się erotyką jak gąbka, stopniowo - najpierw spokojnie, zgodnie ze sztuką malarską, a potem gwałtownie, zgodnie z wyzwoloną emocją. Do mieszaniny uczuć dochodzi w „oku patrzącego”, w przestrzeni odbioru, figura myśli okazuje się mechanizmem wciągającym patrzącego. 


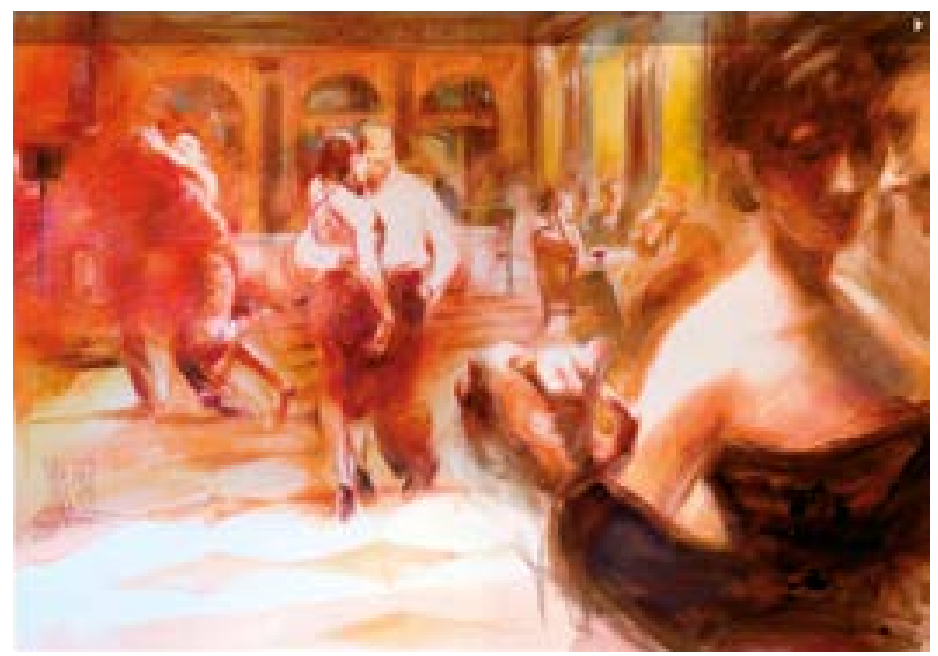

Ryc. 3 Wojciech Pakmur, Milonga brava, 2008, akwarela, tusz, $84 \times 120 \mathrm{~cm}$, kolekcja prywatna

W drugim przedstawieniu [ryc. 3] dominuje kolor. Jak ujmował to Bolesław Leśmian w wierszu Tango (tom Dziejba leśna, 1938) - „staje się ono bezwiednie purpurowe” [Leśmian 2000: 515]. Na pierwszym obrazie Pakmur jedynie zasygnalizował emocje drobnymi plamkami czerwieni, dozując kolor jak aptekarz, teraz pogrążył sylwetki trzech tańczących par w niezwykle ciepłej tonacji. Przedstawienie pary z pierwszego planu oddaje emocje w sposób mimetyczny: mężczyzna jest wpatrzony w kobiecy biust. Środkowe postaci charakteryzuje ciekawy układ, który obrazuje napięcie: on wkłada dłoń do kieszeni i nie dotyka partnerki, ona spuszcza dłoń wzdłuż sukni i nie obejmuje partnera. Twarz mężczyzny jest zamyślona, skoncentrowana, a w przypadku kobiety widać jedynie jej profil (to ponownie rodzaj elipsy). Trzecia para obrazuje zerwanie intelektualnego duktu, tu rękopis malarski staje się nieczytelny. Sylwetka kobiety wspiera się na biodrze mężczyzny, a on ginie w uniesieniu, w czerwonej mgle, zanurza się w jakimś „młodopolskim tumanie”. Kolor nie jest tu środkiem podstawowym, liczy się moment urwania twórczej ścieżki - rodzaj abruptio. „Ciało” już nie milczy, malarz wyzwala pulsującą energię, posługuje się improwizacją, rodzajem nieświadomej pracy. 


\section{Podsumowanie}

Zawieszenie głosu, urwanie myśli, pauza, elipsa - to środki funkcjonujące w sztuce oraz literaturze. Sfera doświadczeń estetycznych odsyła nas na pogranicze świadomości i nieświadomości, domysłu, na skrzyżowanie czasu i przestrzeni. Wymaga powrotu do pierwotnych doznań, gdy granice zmysłów jeszcze nie obowiązywały, gdy nie krępowała ich intelektualna precyzja. Herbert odsłania emocjonalną czeluść kryjącą się na przecięciu wieczoru, zapachów i widoku chmur. Pakmur wybiera ze środków plastycznych te bazujące na fragmencie czy zarysie i prowadzi widza w emocjonalną przestrzeń „uciekającej kreski”. Dogonienie twórcy w jego doznaniach okazuje się niemożliwe: Hals maluje swojego syna, Pakmur - samego siebie w tańcu. Pełną czytelność doznań zapewniłby nam podobny zakres doświadczeń, lecz jeśli ich nie posiadamy, możemy jedynie symulować rozumienie. Dzieła z udziałem aposiopesis wymagają szczególnego trybu interpretacji. Trafnie oddaje go metafora tanecznej improwizacji opisana w eseju Thinking in Movement [Sheets-Johnstone $1981]^{8}$. Gdy podążamy za twórcą, nie możemy tylko poprzestać na obmyślaniu i wykonywaniu poszczególnych kroków, zdani jesteśmy na rodzaj „myślenia w ruchu”, gdyż dopiero taka interpretacja uwzględnia przestrzenny wymiar procesów myślowych i ich dynamiczny charakter. Taki wniosek nie należy do pożądanych w literaturoznawstwie, zakłada bowiem udział nieświadomości w budowaniu przekazu artystycznego, skazuje badaczy na tropienie linii biegnącej od tekstu do mózgu artysty, a ta okazuje się zmienna i drgająca. Nie ma tu mowy o precyzyjnych wnioskach oraz uznanych interpretatorach. Odkrycia z zakresu nauk o umyśle zaczynają decydować o przyszłości humanistyki. Nie pozwalają dłużej ignorować tego, co w umyśle pierwotne, nieświadome, niepodporządkowane intelektualnej dokładności. Takie rozwiązania przyjmuje Marek Hendrykowski, przekonany, że „język ruchomych obrazów jest systemem komunikacyjnym angażującym nie tylko naszą świadomość, lecz obie komplementarne względem 
siebie sfery ludzkiej psyche, to jest świadomość i nieświadomość jednocześnie" [Hendrykowski 2014: 59]. Takie myślenie o sztuce i literaturze prowadzi do zbudowania pomostu pomiędzy naukami przyrodniczymi oraz humanistycznymi, ożywienia haseł „trzeciej kultury”. Proponowany tryb interpretacji oznacza porzucenie metafizyki, jednak - jak trafnie opisywał to już Foucault - zwiastuje jednocześnie narodziny nowoczesności:

Bez wątpienia na poziomie fenomenalnym nowoczesność zaczyna się wówczas, gdy byt ludzki zajmuje miejsce wewnątrz organizmu, w skorupce głowy, w maszynerii mięśni, pośród całej armatury fizjologicznej; gdy zaczyna pochłaniać go praca, której zasada go przerasta, a jej produkt mu się wymyka; kiedy umieszcza swoją myśl w fałdach starszego od siebie języka. [Foucault 2006: 286]

\section{Bibliografia}

Bloom Harold (2003), Poetyckie przejścia, przeł. Adam Lipszyc, „Literatura na Świecie”, nr 9-10, s. 78-120.

Brożek Bartosz (2016), Granice interpretacji, Copernicus. Center Press, Kraków.

Duch Włodzisław (2013), Podstawy nauk neurokognitywnych, Dni Mózgu w Warszawie, Instytut Biologii Doświadczalnej, 17 marca $2013 \mathrm{r}$. [online], [dostęp: 6 kwietnia 2015], http://www.neuroedukacja. net/p/konferencje.html.

Duch Włodzisław (2017), Notatki do wykładów, [online], [dostęp: 21 września 2017], http://www.fizyka.umk.pl/ duch/Wyklady/ Mozg/o5-2-trzy_mozgi.htm.

Foucault Michel (2006), Stowa i rzeczy. Archeologia nauk

humanistycznych, przeł. Tadeusz Komendant, Wydawnictwo słowo/ obraz terytoria, Gdańsk.

Hendrykowski Marek (2014), Semiotyka ruchomych obrazów, Wydawnictwo Naukowe UAM, Poznań.

Herbert Zbigniew (1982), Wiersze zebrane, Czytelnik, Warszawa. Herbert Zbigniew (1998), Epilog burzy, Wydawnictwo Dolnośląskie, Wrocław.

Ingarden Roman (1947), Szkice z filozofii literatury, Spółdzielnia Wydawnicza „Polonista”, Łódź. 
Ingarden Roman (1957), Studia z estetyki, t. 1, PWN, Warszawa.

Johnson Mark (2015), Znaczenie ciała. Estetyka rozumienia ludzkiego, przeł. Jarosław Płuciennik, Wydawnictwo Uniwersytetu Łódzkiego, Łódź.

Koch Christof (2008), Neurobiologia na tropie świadomości, przeł. Grzegorz Hess, Wydawnictwa Uniwersytetu Warszawskiego, Warszawa.

Korwin-Piotrowska Dorota (2015), Białe znaki. Milczenie w strukturze i znaczeniu utworów narracyjnych (na przykładach z polskiej prozy wspótczesnej), Wydawnictwo Uniwersytetu Jagiellońskiego, Kraków.

Krzyżanowski Julian, red. (1969), Nowa księga przysłów i wyrażeń przysłowiowych polskich, t. 1, PIW, Warszawa.

Leśmian Bolesław (200o), Poezje zebrane, oprac. Aleksander Madyda, Algo, Toruń.

Lisecki Wiesław (1993), Vademecum muzycznej „ars oratoria”, „Canor”, nr 3, s. 10-24.

Lorenc Iwona (2001), Świadomość i obraz. Studia z filozofii przedstawienia, Wydawca Scholar, Warszawa.

MacQueen Bruce Duncan (2010), Neurolingwistyczne podejście do teorii aktów mowy, w: Neuropsychologia a humanistyka, red. Maria Pąchalska, Grażyna Ewa Kwiatkowska, Wydawnictwo UmCs, Lublin, s. 177-195.

Mlodinow Leonard (2016), Nieświadomy mózg: jak to, co dzieje się za progiem świadomości, wpływa na nasze życie, przeł. Julia Szajkowska, Prószyński Media, Warszawa.

Okopień-Sławińska Aleksandra (1989), Aposiopesis [hasło], w: Stownik terminów literackich, red. Janusz Sławiński, Wydawnictwo Ossolineum, Wrocław, s. 37-38.

Pąchalska Maria (2010), Wyzwania dla neuropsychologii XxI wieku, w: Neuropsychologia a humanistyka, red. Maria Pąchalska, Grażyna Ewa Kwiatkowska, Wydawnictwo UMCs, Lublin, s. 279-343.

Rogowska Marta Ewa (2012), O intonacyjno-retorycznej roli Norwidowskiej interpunkcji, „Studia Norwidiana”, nr 30, s. 23-38.

Sarbiewski Maciej Kazimierz (1958), Wykłady poetyki, przeł. i oprac. Mieczysław Skimina, Wydawnictwo Polskiej Akademii Nauk, Wrocław.

Schrott Raoul, Jacobs Arthur (2011), Gehirn und Gedicht. Wie wir unsere Wirklichkeiten konstruieren, Carl Hanser Verlag, München [Niemcy]. Sheets-Johnstone Maxine (1981), Thinking in Movement, „The Journal of Aesthetics and Art Criticism”, vol. 39, s. 399-407. 
Subko Barbara (1990), O Norwidowskiej sztuce stawiania kropki, w: Studia nad językiem Cypriana Norwida, red. Jolanta Chojak, Janina Puzynina, Wydawnictwa Uniwersytetu Warszawskiego, Warszawa, s. 103-122.

Szerszenowicz Jacek (2008), Inspiracje plastyczne w muzyce, Akademia Muzyczna im. Grażyny i Kiejstuta Bacewiczów, Łódź.

Tranströmer Tomasz (2012), Vermeer, przeł. Leonard Neuger, w: tegoż, Wiersze i proza: 1954-2004, Kraków, s. 318.

Varela Francisco (2010), Neurofenomenologia. Metodologiczne lekarstwo na trudny problem, przeł. Robert Poczobut, „Avant”, nr 1, s. 31-73.

Wysłouch Seweryna (2009/2010), Przestrzeń jako kategoria transdyscyplinarna, „Estetyka i Krytyka”, nr 1/2, s. 47-60.

Zbigniew Herbert czyta swoje wiersze (1999) [online], Kraków [dostęp: 17 kwietnia 2017], http://www.fundacjaherberta.com/multimedia/ herbert-czyta-swoje-wiersze.

Ziomek Jerzy (2008), O wspótczesności retoryki, w: tegoż, Teoria. Historia. Powinowactwa literatury, wstęp Seweryna Wysłouch, dobór tekstów Janina Abramowska, Ewa Wiegandt, Poznańskie Towarzystwo Przyjaciół Nauk, Poznań, s. 126-147.

Aneta Grodecka Aposiopesis or figures of thought in the space of art and the brain The Author is interested in the states of becoming silent, discontinuing one's utterance, which are associated with certain mechanisms of the functioning of the brain, as well as in the observation of such states in different artistic disciplines. Looking for an answer to the question how aposiopesis operates in words, sounds, and images, she analyzes pieces of music, poems (Zbigniew Herbert's Pora), and examples of visual arts (Wojciech Pakmur's paintings of the tango). In her reconstruction of the research field, the Author refers to rhetoric (Jerzy Ziomek, Seweryna Wysłouch), the philosophy of language (Michel Foucault, Jean-François Lyotard), and neurophenomenology. The aim of the article is to suggest a new mode of reading that seeks inspiration and language in works from the field of neuropsychology (Maria Pąchalska), hermeneutic phenomenology (Mark Johnson), or neurology (António Damásio, Oliver Sacks). The Author's analyses refer to Raoul Schrott and Arthur Jacobs's concept (Gehirn und Gedicht, 2011), and the conclusions confirm that one should not look for a model (pattern) in the reception of art, but describe mental processes. The proposed mechanism of interpretation is most accurately reflected by the metaphor of dance improvisation, where one does not meditate on and 
then perform particular steps and gestures, but "thinks in motion." This mode of reading emphasizes the spatial dimension of thought processes and their dynamic nature.

Keywords: rhetorical figures; neuropsychology; study on reception; philosophy of language; neurophenomenology; neurology; poetry; painting; music.

Aneta Grodecka - dr hab., prof. UAM, polonistka uniwersytecka, zatrudniona w Zakładzie Dydaktyki Literatury i Języka Polskiego; redaktorka „Polonistyki Innowacji”. Autorka książek: Stownik pisarzy i dzieł wspótczesnych (2000), Poeci patrza... Obrazy, wiersze, komentarze (2008), Wiersze o obrazach. Studium z dziejów ekfrazy (2009), Bańka mydlana. Artefakt w przestrzeni pamięci (2013), Stowo i obraz w epoce multiplikacji (2016), podręczników oraz artykułów, które ukazywały się na łamach pism: „Polonistyka”, „Polonistyka Innowacje”, „Polski w Praktyce”, „Katecheta”, „Quart”, „Przestrzenie Teorii”, „Edukacja Humanistyczna. Rocznik Naukowo-Dydaktyczny”, „Litteraria Copernicana”, „Dyskurs. Pismo Naukowo-Artystyczne ASP we Wrocławiu”, „Poznańskie Studia Polonistyczne. Seria Literacka”, „Spotkania Humanistyczne. Międzynarodowy Interdyscyplinarny Rocznik Naukowy”, „Annales Universitatis Mariae Curie-Sklodowska, sectio FF - Philologia”, „Annales Universitatis Paedagogicae Cracoviensis. Studia Poetica”.Jej główną domeną naukową jest pogranicze literatury i sztuk plastycznych, a zajmują ją także zagadnienia z zakresu wielozmysłowości oraz neurofilologii. 
